Eliza Marta Kierska-Woźny ${ }^{1}$

\title{
INTEGRACJA RYNKÓW FINANSOWYCH W UNII EUROPEJSKIEJ
}

\section{Wprowadzenie}

Integracja rynków finansowych jest jednym z etapów integracji gospodarczej. Tendencje do integracji rynków finansowych obserwuje się zarówno w skali całego globu, jak i w różnych jego regionach. Wyróżnia się następujące etapy międzynarodowej gospodarczej integracji regionalnej: strefę wolnego handlu, unię celną, wspólny rynek i unię gospodarczą oraz pieniężną. Integracja rynków finansowych jest elementem trzeciego i czwartego etapu integracji gospodarczej. Wspólny rynek obejmuje m.in. swobodę przepływu kapitału między krajami członkowskimi, a pełna unia gospodarcza - również kwestie wspólnej waluty². Pod pojęciem integracji finansowej rozumie się powszechnie liberalizację przepływów kapitałowych, harmonizację systemów podatkowych i budżetowych, unifikację instytucji bankowych i finansowych oraz integrację rynków kapitałowych ${ }^{3}$. Można wyróżnić następujące etapy integracji finansowej: liberalizacja przepływów kapitałowych, w tym napływ bezpośrednich inwestycji zagranicznych, w dużej mierze dzięki korporacjom transnarodowym, integracja instytucji i systemów finansowych oraz dalsza integracja gospodarcza w zakresie integracji rynków kapitałowych poprzez wprowadzenie wspólnej waluty ${ }^{4}$.

Zaprezentowana definicja silnie akcentuje aspekty instytucjonalne, ważne w przypadku Unii Europejskiej. Tymczasem do integracji rynków finansowych może dochodzić nie tylko na skutek działań władz, ale również w wyniku międzynarodowych procesów wolnego rynku - globalizacji, co podkreśla się w literaturze amerykańskiej. W tym aspekcie pełna integracja rynków finansowych prowadzi do tego, że

\footnotetext{
${ }^{1}$ Autorka jest pracownikiem Narodowego Banku Polskiego. Wszystkie kwestie zawarte w opracowaniu są osobistymi poglądami autorki, niepozostającymi w jakimkolwiek związku z oficjalnym stanowiskiem NBP na temat poruszanych zagadnień.

2 Z. Wysokińska, J. Witkowska, Integracja europejska. Rozwój rynków, Wydawnictwo Naukowe PWN, Warszawa-Łódź 2002, s. 16-17.

${ }^{3}$ K. Zabielski, Finanse międzynarodowe, Wydawnictwo Naukowe PWN, Warszawa 1999, s. 111.

${ }^{4} \mathrm{~K}$. Piech, Integracja rynków finansowych a gospodarka i jej wzrost, „Bank i Kredyt” nr 4, 2007, s. 5.

5 Ibidem.
} 
aktywa o takim samym ryzyku mogą być kupowane w różnych krajach po tej samej cenie, bez względu na ich umiejscowienie.

Integracji rynków finansowych towarzyszy rozwój rynku papierów wartościowych, który jest bardziej płynny, a stopy zwrotu z inwestycji giełdowych są bardziej zmienne i bardziej skorelowane ze zwrotami z rynków światowych niż wcześniej. Integracja często wiąże się także z niższym kosztem kapitału i poprawą ratingu kredytowego, aprecjacją realnych kursów walutowych oraz z większym wzrostem gospodarczym. W praktyce zakres i stopień integracji są różne i często zależą od działalności regulacyjnej władz, przy czym dla wzrostu integracji ważne jest, by uwzględniały one napływ bezpośrednich inwestycji zagranicznych ${ }^{6}$.

Mimo postępującej integracji rynków finansowych w wielu krajach występuje jednak tzw. home bias, czyli względne przeinwestowanie na krajowych, a nie zagranicznych rynkach. Sztandarowym tego przykładem są Stany Zjednoczone, w których w latach 80. XX wieku w krajowe papiery wartościowe lokowano aż 94\% krajowych środków finansowych, choć tamtejszy rynek papierów wartościowych stanowił około $48 \%$ rynku światowego ${ }^{7}$. Tymczasem optymalną wielkością powinno być nie $94 \%$, lecz około $40 \%^{8}$. Co więcej, zjawisko home bias obserwuje się niemal we wszystkich $\mathrm{krajach}^{9}$. Ciekawe jest również to, że zjawisko home bias słabnie wraz z rozwojem globalizacji i integracji regionalnej, szczególnie w strefie euro. Badania przeprowadzone przez grupę ekonomistów z Tilburg University oraz Toulouse Barcelona Business School w 2006 roku dla 25 krajów pokazują, że o ile w ramach Unii Gospodarczej i Walutowej home bias maleje rocznie o 7-8\%, o tyle w krajach UE spoza strefy euro ten efekt nie występuje ${ }^{10}$. Tworzenie bardziej zintegrowanego, wspólnego rynku wspiera zatem integrację rynków finansowych. Integracja europejska jest więc ważna dla postępów międzynarodowej integracji finansowej.

${ }^{6}$ G. Bekaert, C.R. Harvey, R.L. Lumsdaine, Dating the Integration of World Equity Markets, „Working Paper" Nr 6724, NBER, Cambridge 1998, s. 34.

7 K.R. French, J.M. Poterba, Investor diversification and international equity markets, „American Economic Review" Vol. 81, Nr 2, 1991, s. 222-226.

8 K.K. Lewis, Trying to explain home bias in equities and consumption, ,Journal of Economic Literature” Vol. 37, Nr 2, 1999, s. 571-608 oraz M. Britten-Jones, The sampling error in estimates of mean-variance efficient portfolio weights, ,Journal of Finance” Vol. 54, Nr 2, 1994, s. 655-671.

9 K.R. French, J.M. Poterba, op.cit., s. 222-226 oraz I. Cooper, E. Kaplanis, Home bias in equity portfolios, inflation hedging, and international capital market equilibrium, „Review of Financial Studies” Vol. 7, Nr 1, 1994, s. 45-60 oraz L.L. Tesar, I. Werner, Home bias and high turnover, „Journal of International Money and Finance" Vol. 14, Nr 4, 1995, s. 467-492.

10 L. Baele, C. Pungulescu, J.R. Ter Horst, Model Uncertainty, Financial Market Integration and the Home Bias Puzzle, Tilburg University-Toulouse Barcelona Business School, Tilburg-Barcelona 2006. Dokument dostępny na stronie internetowej Social Science Research Network: http://www.ssrn.com (5.04.2007). 
W teorii ekonomii pojawiło się dotąd wiele opinii na temat międzynarodowej integracji gospodarczej i jej oddziaływania na wzrost gospodarczy krajów. Już od początku kształtowania się ekonomii jako nauki byli zarówno zwolennicy wolnego handlu (A. Smith, D. Ricardo), jak i przeciwnicy (merkantyliści). Z jednej strony argumentowano, że pogłębiająca się integracja gospodarcza krajów (wolny handel) doprowadzi do wzrostu ogólnego bogactwa narodów ${ }^{11}$, z drugiej zaś - że zyski z tego będą dzielone nierówno i jeśli jedne kraje będą się bogaciły, to inne będą biedniały. Dalszy postęp teorii ekonomii pokazał, że możliwe jest, by wszystkie kraje zyskiwały na pogłębianiu się integracji. Niemniej jednak szczególnie w krajach rozwijających się zyskała na popularności teoria zależności, powstała w latach 50. XX wieku i sformułowana przez Raula Prebischa ${ }^{12}$.

Podstawą integracji rynków finansowych w Europie były cele gospodarcze. Rozpoczęła się ona wraz z powstaniem Europejskiej Wspólnoty Węgla i Stali. Choć jest wiele dowodów na to, iż integracja opłaci się UE jako całości, nadal pojawiają się głosy, że „zyski” z integracji rozdzielane są nierówno, a nawet że dla niektórych krajów nie jest ona korzystna ${ }^{13}$. Rośnie więc popularność haseł przeciwko wejściu do strefy euro nie tylko wśród populistycznych polityków skrajnych partii o minimalnym poparciu wyborców, ale i wśród przedstawicieli rządów niektórych państw członkowskich UE. Zwrócenie uwagi na aspekty polityczne integracji finansowej jest o tyle ważne, że integracja ta jest $\mathrm{w}$ większości rezultatem działań politycznych i regulacyjnych, a nie spontanicznego rozwoju rynku i technologii ${ }^{14}$.

Tendencje do integracji rynków finansowych wyrażane w działalności polityków gospodarczych opierają się na założeniu, że dzięki niej będzie możliwy większy rozwój krajowych rynków finansowych. Te procesy natomiast są korzystne dla wzrostu gospodarczego. Integracja rynków finansowych powinna zatem - poprzez większy rozwój rynków finansowych - prowadzić do przyspieszenia wzrostu gospodarczego. Gdyby tak nie było, politycy byliby raczej zainteresowani izolacją rynków finansowych swoich krajów i nie podejmowaliby działań na rzecz pogłębienia integracji.

11 Stało się to podstawą koncepcji utworzenia Światowej Organizacji Handlu, międzynarodowych ugrupowań integracyjnych (np. NAFTA) oraz licznych międzynarodowych umów multi- oraz bilateralnych.

12 Teoria ta wskazuje, że bogatsze kraje uzależniają od siebie kraje biedniejsze (przykład m.in. kolonii zamorskich), by jeszcze bardziej się rozwinąć, kosztem właśnie krajów słabszych ekonomicznie. Teoria ta, choć nie zyskała potwierdzenia empirycznego, stała się bardzo popularna wśród polityków (szczególnie Ameryki Łacińskiej), m.in. prowadząc tam do wzrostu nastrojów lewicowych.

13 Wśród grona malkontentów wymienia się np. Włochy, gdzie silnie krytykuje się skutki wejścia tego kraju do strefy euro.

${ }_{14}$ L. Guiso, T. Jappelli, M. Padula, M. Pagano, Financial Market Integration and Economic Growth in the EU, „Working Paper” Nr 118, University of Salerno, Centre for Studies in Economics and Finance, Salerno 2004, s. 2. 
Współczesna teoria wzrostu (endogenicznego) coraz bardziej podkreśla, że to nie rynki pozostawione same sobie, lecz działania rządu wpływają na długookresowe stopy wzrostu gospodarczego - dotyczy to m.in. regulacji handlu międzynarodowego czy rynków finansowych ${ }^{15}$. Pogłębianie integracji gospodarczej w kierunku wprowadzenia jednolitej waluty nie w każdym przypadku prowadzi jednak automatycznie do wyższych stóp wzrostu. Warunkiem koniecznym jest m.in. wcześniejsza synchronizacja cykli koniunkturalnych.

Ponadto należy zauważyć, że w ostatnich latach zmniejsza się rola akumulacji kapitału, a więc i rynków finansowych jako czynnika wzrostu gospodarczego ${ }^{16}$ na rzecz takich czynników, jak wiedza i technologia czy innowacje ${ }^{17}$. Jest to elementem szerszego procesu przemian cywilizacyjnych polegających na przechodzeniu od gospodarki opartej na kapitale do gospodarki, której wzrost opiera się na wiedzy $\mathrm{i}$ innowacjach ${ }^{18}$. Znajduje to też odzwierciedlenie w teorii wzrostu.

Mówiąc o integracji rynków finansowych w UE, mamy na myśli z jednej strony tworzenie możliwości swobodnego przepływu kapitału i usług finansowych w ramach UE, czyli „tworzenie się całości z części” i „scalanie” rynków finansowych poszczególnych krajów. Ten typ integracji nazywamy integracją transgraniczną rynków finansowych. Z drugiej strony mamy „scalanie się przedsiębiorstw” działających w różnych segmentach rynku finansowego, tj. banków, zakładów ubezpieczeń, firm inwestycyjnych, co odbywa się w drodze tworzenia konglomeratów finansowych. Ten rodzaj integracji nazywamy integracją międzysektorową. Integracja rynków finansowych jest zjawiskiem obserwowanym od ponad dwóch dekad. Jej podłożem są procesy zachodzące w gospodarce światowej. Dla Europy szczególnie ważnym czynnikiem sprzyjającym integracji było wprowadzenie w 1999 roku wspólnej waluty krajów unijnych - euro. Proces integracji na europejskich rynkach finansowych zbiegł się z ogólnoświatową tendencją do globalizacji i zwiększania znaczenia sekurytyzacji, które były stymulowane przez liberalizację międzynarodowych przepływów kapitałowych, znoszenie ograniczeń administracyjnych na rynkach finansowych (deregulacja), rozwój informatyki i telekomunikacji. Ze względu na dużą liczbę czynników

15 R. Barro, X. Sala-i-Martin, Economic growth, $2^{\text {nd }}$ ed., The MIT Press, Cambridge (MA)-London 2004, s. 20.

16 K. Piech, Gospodarka oparta na wiedzy w Polsce $i$ w zachodniej Europie z punktu widzenia zmieniającej się roli kapitału, w: Rynek kapitałowy w przededniu integracji Polski z Unią Europejską, red. W. Tarczyński, Polskie Wydawnictwo Ekonomiczne, Szczecin 2004, s. 120-121.

17 Choć wspomina się o roli innowacji finansowych, w tym o venture capital, jako o ważnym czynniku wspomagającym innowacyjność i konkurencyjność gospodarczą.

18 Wyrazem tego była m.in. strategia lizbońska Unii Europejskiej (2000 rok). W jej odnowionej wersji (2005 rok) wyraźnie wskazano na wiedzę i innowacje jako silniki trwałego wzrostu UE (European Council 2005). W koncepcji „gospodarki wiedzy”, czyli gospodarki opartej na wiedzy, mieści się pojęcie innowacyjności, tj. narodowych systemów innowacji. 
wpływających na integrację rynków finansowych trudno jest wyodrębnić wpływ każdego z nich ${ }^{19}$.

Z przejawami integracji rynków finansowych spotykamy się na co dzień jako klienci korzystający z usług finansowych. W Polsce może prowadzić działalność oddział banku zarejestrowanego w dowolnym kraju unijnym. Możemy w nim otworzyć rachunek lub zaciągnąć kredyt (integracja transgraniczna), bądź, idąc do oddziału banku, możemy nabyć produkt inny niż bankowy, np. jednostki uczestnictwa funduszy inwestycyjnych, czy produkt mieszany (hybrydowy), np. lokatę inwestycyjną (integracja międzysektorowa). Kwestie integracji rynków finansowych doczekały się wielu badań naukowych i zasługują także na popularyzację ze względu na rolę, jaką rynki te odgrywają i będą odgrywać w przyszłości w życiu codziennym.

Mówimy o rynkach finansowych, a nie rynku finansowym, ponieważ wyróżniamy kilka jego segmentów, tj. bankowy, ubezpieczeniowy i kapitałowy ${ }^{20}$. Według innych kryteriów ${ }^{21}$ można wyróżnić rynek zindywidualizowanych transakcji finansowych o charakterze depozytowym, kredytowym i ubezpieczeniowym oraz rynek powszechnych transakcji finansowych bądź - według innego kryterium - rynek pieniężny i kapitałowy. Podane klasyfikacje oraz inne dostępne w literaturze odzwierciedlają różnorodność rynków finansowych.

Unia Europejska - obok USA i mniej znaczącej Japonii - jest jednym z trzech najważniejszych graczy na światowych rynkach finansowych. Według danych z 2004 roku $^{22}$, obejmujących tylko kraje „starej” Unii (UE-15), UE miała od 20\% do 40\% udziału w poszczególnych segmentach rynków finansowych. W rynku bankowym jej udział wynosił $45 \%$ i był dominujący. Udziały w rynku papierów dłużnych, ubezpieczeniowym i reasekuracyjnym były podobne jak w przypadku USA. W porównaniu z dominującymi Stanami Zjednoczonymi znacznie niższy był udział rynku akcji - wynosił on $25 \%$, a funduszy inwestycyjnych - 34\%. Unia Europejska, przyjmując w 2000 roku strategię lizbońską, podjęła m.in. wyzwanie w postaci „dogonienia” gospodarki Stanów Zjednoczonych. Pomocna w tym miała być zmiana struktury rynków finansowych, tj. wzmocnienie znaczenia rynku kapitałowego jako źródła pozyskiwania kapitału.

19 C. Stirbu, Financial market integration in a wider European Union, „Discussion Paper” Nr 297, Hamburg Institute of International Economics, Hamburg 2004, s. 7.

${ }^{20}$ M. Iwanicz-Drozdowska, Integracja rynków finansowych - jej rodzaje i znaczenie, „Bank i Kredyt” nr 1, 2007, s. 5.

${ }^{21}$ Z. Polański, Wprowadzenie. System finansowy we współczesnej gospodarce rynkowej, w: System finansowy w Polsce, red. B. Pietrzak, Z. Polański, B. Woźniak, Wydawnictwo Naukowe PWN, Warszawa 2003, s. 29.

${ }_{22}$ Commission of the European Communities, Financial Integration Monitor 2006, „Commission Staff Working Document” Nr SEC(2006)1057, Brussels 2006, s. 2. 


\section{Sposoby mierzenia integracji}

Mówiąc o integracji, należy odnieść się nie tylko do samej idei, ale także określić skalę integracji. Jest to szczególnie ważne, jeżeli chce się ocenić efekty wprowadzonych rozwiązań regulacyjnych. Mierniki zdefiniowane w literaturze poświęconej integracji finansowej można podzielić na cztery podstawowe kategorie ${ }^{23}$, tj. wskaźniki integracji rynku kredytowego i papierów dłużnych, wskaźniki integracji rynku akcji, wskaźniki integracji oparte na decyzjach ekonomicznych gospodarstw domowych i firm oraz wskaźniki różnic instytucjonalnych, które mogą wpływać na segmentację rynku finansowego. Istotnym problemem w ocenie integracji jest nie tylko wybór odpowiednio skonstruowanego wskaźnika, ale także dostępność danych, które są podstawą do jego wyliczenia. Najłatwiejszy jest dostęp do danych rynkowych typu ceny papierów wartościowych, stopy procentowe, informacje o strukturze aktywów publikowane przez fundusze inwestycyjne.

Jeśli chodzi o mierniki integracji rynku kredytowego i papierów dłużnych, to wyróżniono cztery typy miar integracji ${ }^{24}$. Pierwszy typ miar odnosił się do różnic w poziomie stóp procentowych, a więc zmiennych łatwo osiągalnych, np. dla rynku międzybankowego, obligacji, rynku kredytów hipotecznych i korporacyjnych. Drugi typ miar dotyczył struktury portfela inwestycyjnego funduszy inwestycyjnych, tj. rynku pieniężnego i rynku obligacji. Kolejna grupa miar odnosiła się do różnic w wysokości opłat pobieranych przez banki za przelewy transgraniczne. Ostatnia grupa miar dotyczyła liczby i udziału banków zagranicznych w rynkach narodowych. Wszystkie podane mierniki integracji są możliwe do wyliczenia i monitorowania ${ }^{25}$.

W pozostałych trzech kategoriach wyróżniono mniejszą liczbę mierników integracji. W zakresie integracji rynku akcji przyjęto, że dobrym miernikiem może być korelacja stóp zwrotu z akcji, bądź lokowanie przez instytucjonalnych inwestorów aktywów na rynkach zagranicznych. Zachowanie gospodarstw domowych i przedsiębiorstw proponuje się mierzyć, stosując korelację pomiędzy oszczędnościami a inwestycjami, korelację wzrostu konsumpcji oraz ocenę relacji fuzji i przejęć o charakterze transgranicznym do krajowych fuzji i przejęć. Ocena różnic instytucjonalnych sprowadza się głównie do analizy zbieżności krajowych przepisów prawnych ${ }^{26}$.

${ }_{23}$ M. Pagano, Measuring financial integration [materiały konferencyjne], European Central Bank, Frankfurt 2002, s. 2.

24 Ibidem, s. 2-3

${ }_{25}$ M. Iwanicz-Drozdowska, Integracja rynków..., s. 9.

26 M. Pagano, op.cit., s. 4-5. 
Na zamówienie Komisji Europejskiej przeanalizowano stopień integracji rynków finansowych po wprowadzeniu wspólnej waluty, stosując powyższe mierniki. Najbardziej zintegrowany był rynek międzybankowy i rządowych papierów dłużnych. W przypadku rynku kredytowego nie można było mówić o integracji ${ }^{27}$, o czym świadczyła także niewielka obecność banków zagranicznych, z wyjątkiem Irlandii, Luksemburga i Wielkiej Brytanii. Można było stwierdzić rosnącą integrację rynku akcji w Eurolandzie, chociaż badane mierniki nie zawsze właściwie oddawały ocenę skali integracji. Wskaźniki decyzji gospodarstw domowych sygnalizowały wzrost integracji, którego nie było z kolei w przypadku fuzji i przejęć przedsiębiorstw. Regulacje prawne charakteryzowały się dużym zróżnicowaniem, co mogło niekorzystnie wpływać na możliwości integracji rynków finansowych. Badanie to pokazało także, że konieczne jest pozyskiwanie dodatkowych danych, aby móc lepiej mierzyć integrację ${ }^{28}$.

Komisja Europejska od 2004 roku publikuje opracowania dotyczące integracji finansowej. W raporcie dotyczącym integracji finansowej z 2004 roku działalność transgraniczna (cross-border) występowała głównie na rynkach hurtowych, natomiast w przypadku rynku usług detalicznych była nadal rzadkością. Szczególnie odzwierciedlał to kształt sieci dystrybucji, która miała charakter lokalny ${ }^{29}$. Raport dotyczący integracji finansowej z 2005 roku potwierdził to, można jednak było zauważyć pewien postęp. Zwiększył się bowiem stopień korzystania z rachunków bankowych z 4\% do 5\% obywateli UE i kart kredytowych z 2\% do 3\% z innego kraju członkowskiego. Wiązało się to jednak głównie z migracjami po wejściu do UE nowych krajów. Najbardziej zwiększyła się integracja w przypadku funduszy inwestycyjnych. Zgodnie $\mathrm{z}$ deklaracjami klientów zakres korzystania z usług z innego kraju członkowskiego może wzrosnąć w ciągu pięciu lat: w przypadku rachunków bankowych - do 15\%, w przypadku kart kredytowych - do $12 \%$, a w przypadku polis ubezpieczeń motoryzacyjnych - do $8 \%$, z obecnych $2 \%$. W raporcie dotyczącym integracji finansowej w 2006 roku nie zaprezentowano informacji na temat rynku bankowego, który nadal jest podstawowym segmentem rynku finansowego UE. Większą uwagę poświęcono ubezpieczeniom, funduszom emerytalnym i inwestycyjnym. Integracja tych rynków nieco się zwiększyła, potrzebne jednak są, w przypadku zakładów ubezpieczeń,

27 Pewne przyspieszenie integracji można było zaobserwować w przypadku rynku kredytów hipotecznych.

${ }^{28}$ K. Adam, T. Jappelli, A. Menichini, M. Paduka, M. Pagano, Analyse, compare, and apply alternative indicators and monitoring methodologies to measure the evolution of capital market integration in the European Union, Centre for Studies in Economics and Finance, University of Salerno, Salerno 2002, s. 50-51.

29 Commission of the European Communities, Financial Integration Monitor 2004, „Commission Staff Working Document" Nr SEC(2004)559, Brussels 2004, s. 10-11. 
stosowne zmiany legislacyjne, aby proces ten przyspieszyć. W przypadku funduszy inwestycyjnych istotną barierą integracji były wysokie opłaty dystrybucyjne.

\section{Integracja transgraniczna}

Jak wspomniano, praktycznym przejawem integracji transgranicznej jest np. funkcjonowanie na polskim rynku oddziałów instytucji kredytowych z innych krajów unijnych. Jest to możliwe dzięki tzw. zasadzie jednolitego paszportu europejskiego. Polega ona na tym, że bank, nazywany w prawodawstwie UE instytucją kredytową, ma prawo do prowadzenia działalności nie tylko w kraju Unii, w którym otrzymał licencję, ale także w innych krajach unijnych - za pośrednictwem oddziałów. Wymagane jest tylko stosowne powiadomienie organów nadzorczych. Warto także wspomnieć, że istnieje możliwość świadczenia usług bankowych bez fizycznej obecności oddziału, co nazywa się działalnością transgraniczną. W dobie internetu taka forma pozyskiwania klientów i świadczenia usług jest jak najbardziej możliwa do wykorzystania. Podobne rozwiązania funkcjonują także w innych segmentach rynku finansowego, tj. ubezpieczeniowym i inwestycyjnym.

Jednolity paszport europejski wiąże się także z określoną odpowiedzialnością instytucji sprawującej nadzór nad działalnością banków i instytucji gwarantującej depozyty z kraju, w którym wydano licencję (kraj pochodzenia). Nadzór nad działalnością oddziału sprawuje nadzorca $\mathrm{z}$ kraju pochodzenia i to on ocenia kondycję oraz bezpieczeństwo tego oddziału. Instytucja gwarantująca depozyty z kraju pochodzenia gwarantuje je także w oddziałach zagranicznych. Nabywając więc usługi oddziału instytucji kredytowej z innego kraju UE, klient korzysta z mechanizmów ochronnych kraju pochodzenia, a nie kraju, w którym taki oddział jest zlokalizowany (kraj goszczący). Odmiennie wygląda sytuacja w przypadku posiadania przez bank z innego kraju unijnego spółki córki, czyli banku utworzonego zgodnie np. z polskim prawem i licencjonowanego przez polską instytucję nadzorczą. Według statystyk z 2005 roku $^{30} \mathrm{w}$ krajach UE-25 działało 601 oddziałów z innych krajów UE - najwięcej w Wielkiej Brytanii, we Włoszech i w Niemczech. We wszystkich krajach UE było ogółem 201259 oddziałów. Liczba oddziałów z krajów spoza UE wynosiła 208, najwięcej działało w Wielkiej Brytanii ${ }^{31}$.

\footnotetext{
30 European Central Bank, EU Banking structures, European Central Bank, Frankfurt 2006, s. 12.

31 M. Iwanicz-Drozdowska, Integracja rynków..., op.cit., s. 11.
} 
Bardziej popularną formą zdobywania klientów i rynków w Europie Środkowej i Wschodniej jest posiadanie przez banki z krajów „starej” Unii spółek córek, tzw. spółek zależnych. To właśnie ta forma organizacyjna prowadzenia działalności dominuje. Skutkuje ona wysokim udziałem kapitału zagranicznego w sektorze bankowym krajów naszego regionu. Integracja transgraniczna odbywała się w takim przypadku w drodze tworzenia od podstaw banku w danym kraju, bądź przejmowania udziałów w prywatyzowanych bankach lub od dotychczasowych inwestorów prywatnych. W nowych krajach członkowskich (UE-10) udział spółek zależnych od banków z krajów UE-15 wynosił 56,2\%, a 4,6\% w przypadku oddziałów. Jako przyczyny takiej sytuacji można podać lepszą izolację ryzyka z perspektywy spółki matki oraz notowanie spółki zależnej na lokalnej giełdzie, co zwiększa przejrzystość funkcjonowania całej grupy ${ }^{32}$.

Od 2000 roku do pierwszej połowy 2006 roku miało miejsce 429 fuzji bądź przejęć wewnątrzkrajowych w sektorze bankowym oraz 221 fuzji bądź przejęć transgranicznych $^{33}$. Fuzje i przejęcia transgraniczne, w szczególności wykraczające poza sektor bankowy, przyczyniają się do powstawania ponadnarodowych grup finansowych, tzw. konglomeratów finansowych. Jednym z ich celów jest świadczenie różnorodnych usług finansowych "pod jednym dachem” (allfinanz, one-stop shopping). W ramach Financial Services Action Plan dążono do zniesienia barier dla fuzji i przejęć transgranicznych, a więc z czasem możliwe będzie ich zintensyfikowanie.

Innymi przejawami integracji transgranicznej są: silnie zintegrowany rynek międzybankowy, a także np. nabywania akcji na rynkach zagranicznych przez fundusze inwestycyjne. Wprowadzenie euro przyczyniło się do powstania w UE drugiego co do wielkości rynku obligacji. Do 1998 roku rynek obligacji korporacyjnych był słabo rozwinięty, zaś po wprowadzeniu wspólnej waluty jego rozwój został przyspieszony ${ }^{34}$.

Istotną rolę dla integracji transgranicznej odegrały podejmowane w Unii Europejskiej działania o charakterze regulacyjnym, które przyczyniły się do ograniczenia barier dla powstawania zintegrowanych rynków finansowych. Strategie rozwoju określono w Financial Services Action Plan, w którym zdefiniowano trzy główne cele, tj. stworzenie jednolitego hurtowego rynku usług finansowych, stworzenie otwartego i bezpiecznego detalicznego rynku usług finansowych oraz przygotowanie odpowiednich regulacji nadzorczych i systemu nadzoru. Główne działania związane z tworzeniem jednolitego rynku hurtowego sprowadzały się do ujednolicenia kwestii związanych z ofertami publicznymi i prospektami emisyjnymi, venture capital w celu ułatwienia finansowania małymi średnim przedsiębiorstwom rozpoczynającym

32 European Central Bank, EU Banking..., op.cit., s. 13.

33 M. Iwanicz-Drozdowska, Integracja rynków..., op.cit., s. 12.

34 C. Stirbu, op.cit., s. 8. 
działalność, raportowania spółek oraz zasad rachunkowości. Dla rynku detalicznego jednym z priorytetów było promowanie jednakowego rozumienia pojęć profesjonalnego uczestnika rynku i nieprofesjonalnego, tj. indywidualnego uczestnika rynku, a także wzmocnienie zaufania konsumentów do usług finansowych. Urzeczywistnianie trzeciego celu polegała głównie na zorganizowaniu współpracy pomiędzy różnymi ciałami sprawującymi nadzór, uaktualnieniu regulacji kapitałowych oraz uregulowaniu funkcjonowania konglomeratów finansowych. Jedną z istotnych zmian było wprowadzenie czterostopniowego procesu przyjmowania i wdrażania regulacji, nazywanego procesem Lamfalussy'ego ${ }^{35}$.

\section{Integracja międzysektorowa}

Jak wspomniano, jednym ze skutków fuzji i przejęć może być powstawanie konglomeratów finansowych, które dążą do oferowania klientom jak najszerszej palety usług. Są one ucieleśnieniem integracji międzysektorowej. Za podstawowe bodźce stymulujące integrację międzysektorową należy uznać zmniejszanie roli banków jako pośredników finansowych, tj. dezintermediację oraz chęć dywersyfikacji przychodów, a także większą wiedzę i świadomość klientów dotyczącą możliwości lokowania oszczędności ${ }^{36}$.

Zjawisko dezintermediacji dotknęło głównie rynek bankowy Stanów Zjednoczonych. W latach 80 . XX wieku znaczna część klientów korporacyjnych zdecydowała się na pozyskiwanie środków z rynku kapitałowego, zamiast korzystania z kredytów bankowych. Na rynku europejskim także można było zaobserwować taką tendencję, chociaż kredyt bankowy nadal jest istotnym źródłem finansowania. O zjawisku dezintermediacji można mówić również w odniesieniu do klientów detalicznych, którzy, mając większą wiedzę na temat możliwości lokowania oszczędności, stopniowo zmniejszali swoje zainteresowanie depozytami bankowymi.

Banki i inni pośrednicy finansowi, podobnie jak przedsiębiorstwa, poszukiwali możliwości dywersyfikacji źródeł przychodów. Jednym ze sposobów było rozszerzanie zakresu działalności na inne segmenty rynku finansowego, co w szczególności odpowiadało oczekiwaniom klientów. Banki i zakłady ubezpieczeń budowały wokół siebie duże struktury typu konglomeratu, które w rezultacie fuzji i przejęć transgranicznych mają w większości charakter ponadnarodowy. W okresie dekoniunktury

\footnotetext{
${ }_{35}$ M. Iwanicz-Drozdowska, Integracja rynków..., op.cit., s. 12-13.

36 Ibidem, s. 13.
} 
część struktur konglomeratowych „odchudzała się". Było to dobrze widoczne na przykładzie niemieckich grup kapitałowych, rezygnujących z tych rodzajów działalności, które przyczyniły się do powstania strat. Proces ten określa się jako demerger. Należy bowiem pamiętać, że podstawowym celem procesów konsolidacji - fuzji i przejęć jest zwiększanie wartości dla akcjonariuszy, co wymaga osiągania zysków na odpowiednim poziomie.

Jak wspomniano na początku opracowania, klienci pośredników finansowych coraz częściej nabywają mieszane (hybrydowe) produkty finansowe. Przykładem takiego produktu jest lokata inwestycyjna, tj. lokata, której oprocentowanie zależy np. od zmiany wartości indeksu giełdowego bądź innego miernika ustalonego w umowie. Inne przykłady to popularna ze względów podatkowych polisa ubezpieczeniowa $\mathrm{z}$ funduszem inwestycyjnym czy też kredyt z opcją wcześniejszej spłaty. Produkty te można uznać za bezpośredni przejaw występowania integracji międzysektorowej, która przynosi nowe możliwości klientom i samym pośrednikom. Ich pojawienie się na rynku wynika z oczekiwań klientów i dążenia do jak najkorzystniejszego ulokowania swoich oszczędności.

Za czynnik stymulujący integrację międzysektorową można uznać także rynek transferu ryzyka kredytowego (credit risk transfer - CRT), dzięki któremu ryzyko kredytowe $^{37}$ jest przenoszone $\mathrm{z}$ banków na inne grupy pośredników finansowych. Ryzyko można przenieść dzięki takim instrumentom, jak ubezpieczenie kredytu, gwarancje finansowe czy dynamicznie rozwijające się na rynkach światowych derywaty kredytowe (kredytowe instrumenty pochodne) ${ }^{38}$. Banki są jednym z głównych graczy na tym rynku - zarówno jako podmioty sprzedające, czyli pozbywające się, jak i kupujące ryzyko kredytowe. Jako kupujący bardzo często występują zakłady ubezpieczeń i fundusze hedgingowe. Przenoszenie ryzyka kredytowego na podmioty inne niż banki przyczynia się do zacierania granic pomiędzy różnymi segmentami rynków finansowych. Jak wskazują badania Committee on the Global Financial System ${ }^{39}$, instytucje objęte badaniem nie wykorzystywały na dużą skalę CRT do przenoszenia ryzyka w ramach tej samej grupy kapitałowej. Sugeruje to, że ryzyko kredytowe

37 W literaturze i praktyce funkcjonują różne definicje ryzyka kredytowego. Można je przedstawić jako sytuację, w której dłużnik nie reguluje swoich zobowiązań wobec wierzyciela. Wierzyciel ponosi w związku z tym straty.

38 Kredytowe instrumenty pochodne to instrumenty finansowe, które zawierają w sobie mechanizmy kompensujące straty podmiotu sprzedającego ryzyko kredytowe. Uruchomienie tych mechanizmów następuje w przypadku wystąpienie tzw. zdarzenia ryzyka kredytowego.

39 Committee on the Global Financial System, Credit risk transfer, CGFS Publications Nr 20, Basel 2003, s. 24. Dokument dostępny na stronie internetowej The Bank for International Settlements: http:// www.bis.org (4.04.2009). 
sprzedawano poza grupę kapitałową. Rozwój rynku kredytowych instrumentów pochodnych powinien więc przyczyniać się do wzrostu integracji międzysektorowej.

\section{Integracja rynków finansowych a gospodarka - nieprzygotowanie instytucjonalne do liberalizacji rynków finansowych}

Integracja rynków finansowych przynosi korzyści całemu światu - przekonanie to legło u podstaw tworzenia Międzynarodowego Funduszu Walutowego (MFW). Kraje członkowskie MFW, przyjmując obowiązki wynikające z art. VIII statutu MFW, zobowiązują się nie stosować restrykcji wobec transakcji bieżących (na mocy art. XIV można przejściowo odejść od realizacji tego artykułu). W przypadku niedostosowań instytucjonalnych i po stronie polityki gospodarczej integracja finansowa może jednak mieć negatywne, przynajmniej przejściowo, rezultaty dla gospodarki. Może bowiem wystąpić kryzys finansowy. Pojawiają się opinie, że ceną za wzrost integracji rynków finansowych jest wzrost ryzyka wystąpienia kryzysów finansowych ${ }^{40}$.

W XIX wieku i na początku XX wieku kryzysy finansowe, w tym te o charakterze międzynarodowym, były stosunkowo częstym zjawiskiem. Szczególnie negatywny charakter miał na początku lat 30. XX wieku tzw. Wielki Kryzys. Po II wojnie światowej ich liczba znacznie spadła. Okres korzystnego rozwoju gospodarki światowej zakończył się jednak dwoma kryzysami naftowymi, załamaniem systemu z Bretton Woods i światowym kryzysem zadłużeniowym od 1982 roku. Lata 90. XX wieku i początek XXI wieku to okres nasilonego występowania różnego rodzaju kryzysów finansowych, z których najważniejszy to "grypa azjatycka” z lat $1997-1998^{41}$ oraz obecny ogólnoświatowy kryzys ekonomiczny rynku finansowego i bankowego, który swój początek wziął w Stanach Zjednoczonych w 2007 roku.

Widzimy zatem, że kryzysy finansowe nie są zjawiskiem rzadkim, a wręcz odwrotnie - w historii gospodarczej świata pojawiały się dość często. Oznacza to, że wraz ze wzrostem gospodarczym stymulowanym rozwojem rynków finansowych należy zwracać większą uwagę na właściwą regulację rynków - by nie dopuścić do

${ }^{40}$ K. Piech, op.cit., s. 19.

41 Przykładowo, Kaminsky, Reinhart (1996) w latach 1970-1995 w 20 krajach Azji, Europy, Ameryki Łacińskiej i Bliskiego Wschodu zidentyfikowali 25 kryzysów bankowych i 71 kryzysów bilansu płatniczego; w latach 70. liczba kryzysów wyniosła, odpowiednio, tylko 3 i 25 . Z 25 kryzysów bankowych 18 było poprzedzonych liberalizacją sektora finansowego (w ciągu poprzedzających je pięciu lat). 
wystąpienia kryzysu ${ }^{42}$. Należy zauważyć, że okresy wzrostu gospodarczego są dłuższe niż okresy trwania kryzysów gospodarczych i dlatego mimo występowania zjawisk kryzysowych świat się rozwija.

Liberalizacja rynków finansowych niesie wiele korzyści: otwarcie krajowych rynków na dopływ kapitału pozwala uzupełnić brakujące zasoby kapitałowe zagranicznymi oszczędnościami. Pozwala to m.in. na sfinansowanie większych inwestycji, a zatem przyczynia się do przyspieszenia wzrostu gospodarczego i zwiększa konkurencyjność krajowych instytucji finansowych. Liberalizacja oznacza również wystąpienie zagrożeń, spowodowanych możliwością zarówno odpływu kapitału, jak i napływu. Do wcześniejszych rozważań można dodać, że problemy związane z nieodpowiednim przygotowaniem liberalizacji rynków finansowych ujawniają się szczególnie w okresie dynamicznego wzrostu gospodarczego świata (przykład kryzysów wschodnioazjatyckich). Występuje wtedy przejściowa nadpłynność światowego systemu finansowego, która jest lokowana w krajach mających dobre perspektywy rozwojowe ${ }^{43}$. W sytuacji nadpłynności menedżerowie instytucji finansowych mają tendencje do przeceniania możliwych zysków - w porównaniu z ponoszonym ryzykiem. Nie jest to zachowanie racjonalne, lecz podejmowane pod wpływem „euforii”44. Menedżerowie natomiast są raczej nagradzani za zyski, niż karani za straty, co sprawia, że chętniej akceptują wyższe ryzyko. Przykładem mogą być pożyczki dla podmiotów wschodnioazjatyckich i meksykańskich przed wystąpieniem tam kryzysów finansowych ${ }^{45}$ oraz pożyczki hipoteczne udzielane przez banki przy wysokim ryzyku spłaty, często osobom o marginalnych możliwościach finansowych (subprime mortgage) przed wystąpieniem ogólnoświatowego kryzysu ekonomicznego rynku finansowego i bankowego w latach 2007-2009, który rozpoczął się od zapaści rynku pożyczek hipotecznych wysokiego ryzyka w Stanach Zjednoczonych. Fundusze inwestycyjne otrzymują zatem silne bodźce do inwestowania w ryzykowne przedsięwzięcia. Ponadto przemiany rynków finansowych sprawiają, że nie tylko fundusze inwestycyjne, ale i banki stają się pośrednikami finansowymi - odchodząc od swojej tradycyjnej roli jako bezpiecznego pośrednika

42 A. Kruger, Financial Markets and Economic Growth, przemówienie wygłoszone 28.09.2006 w Tokio. Dokument dostępny na stronie internetowej The International Monetary Fund: http://www.imf.org (4.04.2009).

${ }^{43}$ Kraje wschodnioazjatyckie przed kryzysem cieszyły się np. dużą wiarygodnością w oczach agencji ratingowych, nie mówiąc o wysokich stopach wzrostu.

${ }^{44}$ C.P. Kindleberger, Szaleństwo, panika, krach. Historia kryzysów finansowych, WIG-Press, Warszawa 1999, s. 43-44.

45 T. Puzyrewicz, Przemiany globalnego rynku kapitałowego a kryzysy walutowe, w: Rynek kapitałowy - mechanizm, funkcjonowanie, podmioty, red. T. Bernat, Polskie Towarzystwo Ekonomiczne, Szczecin 2004, s. 125. 
między strumieniami prywatnych oszczędności a strumieniami długookresowych kredytów ${ }^{46}$.

Ponadto do kryzysu może się przyczynić nie tylko odpływ kapitału zagranicznego, ale nawet spowolnienie jego napływu do kraju w porównaniu z wcześniejszymi okresami, a dokładniej - ryzyko rośnie wraz ze wzrostem zmienności (fluktuacji) międzynarodowych przepływów kapitałowych.

Warto również podkreślić, że nie tylko odpływ, ale i napływ kapitału ${ }^{47}$ może być niekorzystny, ponieważ zwiększenie wartości pieniądza w obiegu utrudnia politykę antyinflacyjną, zmuszając do podwyższania stóp procentowych, co chłodzi koniunkturę, bądź „sterylizacji”, poprzez operacje otwartego rynku lub rezerwy obowiązkowe. Ponadto napływ waluty zagranicznej prowadzi do aprecjacji waluty krajowej, co zmniejsza konkurencyjność cenową eksportu i negatywnie oddziałuje na wzrost gospodarczy. W celu ograniczenia napływu kapitału stosuje się np. nakazy odprowadzania na rachunek nieoprocentowany w banku centralnym części kwoty, która napływa do kraju czy obowiązek pozostawiania kapitału w kraju przez minimalny, określony czas, np. rok. Aby ograniczyć odpływ kapitału, wprowadza się np. podatek od zakupów za waluty obce, w tym zakupów lokalnej waluty, podwójny kurs walutowy - inny w przypadku transakcji handlowych, a inny, mniej korzystny w przypadku inwestora zagranicznego, kapitałowych, konieczność uzyskiwania zgody banku centralnego na odpływ z kraju większych kwot za granicę. Doświadczenia niektórych krajów rozwijających się pokazały, że wprowadzanie tego typu ograniczeń administracyjnych, zwłaszcza konieczność uzyskiwania zgód i zezwoleń, było korupcjogenne ${ }^{48}$.

Podsumowując, do wzrostu integracji rynków kapitałowych należy się przygotować, w tym od strony instytucjonalnej ${ }^{49}$. Rozrost instytucji może jednak ograniczać rozwój rynków (bariery administracyjne, korupcja). Niezbędna jest zatem równowaga, by z jednej strony eliminować błędy rynku, z drugiej zaś minimalizować błędy rządu.

46 K. Piech, op.cit., s. 20-21.

47 Warto zauważyć, że kwestia ta może być ważna także dla naszego kraju w związku z napływem funduszy unijnych i inwestycji zagranicznych o dużej wartości (na co wskazują polskiemu rządowi eksperci np. z MFW). Sytuacja taka nosi ogólniejszą nazwę „choroby holenderskiej” (po odkryciu gazu w Holandii i rozpoczęciu jej eksportu pogorszyła się konkurencyjność eksportu holenderskiego w wyniku aprecjacji waluty).

48 Ibidem, s. 22.

49 Zwiększenie roli instytucji we wzroście i rozwoju gospodarczym w ostatnich latach wskazuje coraz więcej ekonomistów. 


\section{Integracja rynków finansowych w UE a gospodarka}

Pokazano wyżej, że nieprzygotowanie rynków finansowych do integracji podczas dynamicznego wzrostu gospodarczego dzięki rozwojowi rynków finansowych może prowadzić do kryzysów finansowych i gospodarczych. Właściwie przygotowana i przeprowadzona integracja może jednak przynieść wiele korzyści, czego przykładem są procesy w UE, rozpoczęte od liberalizacji przepływów kapitałowych i prowadzące do unii walutowej. Ponadto według Europejskiego Komisarza ds. Rynku Wewnętrznego i Usług ${ }^{50}$ integracja rynków finansowych przynosi Europie wiele korzyści. Po pierwsze, dla handlu międzynarodowego i inwestycji ponadgranicznych - rynki europejskie stają się bardziej atrakcyjne dla inwestycji spoza UE i w ramach UE. Po drugie, dla konkurencji - zwiększa się konkurencja między dostawcami usług, co obniża ceny usług, poprawia ich jakość i różnorodność. Po trzecie, łatwiej osiągnąć zyski z korzyści skali, co prowadzi do oferowania lepszych i bardziej innowacyjnych produktów i usług po niższych cenach oraz wspomaga wzrost małych i średnich przedsiębiorstw z sektora niefinansowego. Po czwarte, zmniejszają się obciążenia administracyjne, choć początkowo wymaga to poniesienia kosztów związanych $\mathrm{z}$ ich ujednoliceniem. Po piąte, wzrasta różnorodność produktów, poprawia się ich jakość i obniżają ceny, a także zwiększają się możliwości inwestycyjne, stopy zwrotu z inwestycji i spadają koszty finansowe. Po szóste, wraz z integracją rośnie stabilność finansowa, sektor publiczny może zaspokoić swoje potrzeby po niższych kosztach, czyli ogólniej - rośnie konkurencyjność gospodarek. Wiedząc to, Komisja Europejska w 1999 roku wdrożyła Financial Services Action Plan. Do tego czasu integracja rynków finansowych w UE była bardzo ograniczona.

Na początkowych etapach integracji europejskiej integracja rynków finansowych nie odgrywała znacznej roli. Na mocy Traktatu rzymskiego swoboda przepływu kapitału była dość ograniczona, ponieważ kraje członkowskie chciały mieć większą kontrolę nad ich gospodarkami, rynkiem wewnętrznym czy sytuacją pieniężną. Obawiano się zwłaszcza zakłóceń po stronie bilansu płatniczego, które mogłyby być wywołane gwałtownymi ruchami kapitału, a kraje członkowskie chciały mieć niezależne od siebie instrumenty radzenia sobie $\mathrm{z}$ takimi zagrożeniami.

Mimo przejściowej liberalizacji przepływów finansowych na mocy dwóch dyrektyw z 1960 i 1962 roku, które zniosły ograniczenia dewizowe w zakresie przepływu towarów i osób, niektóre kraje członkowskie, m.in. Francja i Włochy, szeroko

50 C. McCreevy, Financial Capital Markets Integration in Europe, SPEECH/06/313, Reuters Newsmaker Event, Shangai, 18.05.2006, s. 4. Dokument dostępny na stronie internetowej Unii Europejskiej: http:// europa.eu (6.04.2009). 
stosowały dozwolone klauzule ochronne. Do ograniczonych postępów w liberalizacji rynków przyczyniło się też załamanie systemu z Bretton Woods na początku lat 70. XX wieku.

W latach 80. XX wieku wraz z poprawą sytuacji gospodarczej po dwóch kryzysach naftowych nasiliły się procesy integracji rynków finansowych w Europie. Rządy zaczęły coraz bardziej przekonywać się do korzyści z integracji rynków finansowych. Pojawiły się także rozwiązania technologiczne, które ułatwiły ten proces. Integrację tę wywołał wzrost współzależności gospodarczej, wywołanej wzrostem wymiany handlowej, krajów Europejskiej Wspólnoty Gospodarczej (EWG) ${ }^{51}$. Skutkiem tych zmian było wprowadzenie w 1984 roku ściślejszego nadzoru nad stosowaniem przez kraje EWG klauzul ochronnych w celu ograniczenia ich stosowania, a także dyrektyw z 1986 roku i 1988 roku, znacznie liberalizujących przepływy kapitałowe ${ }^{52}$.

W wyniku nasilania się procesów integracji rynków finansowych w Europie znacznie wzrosła wartość przepływu kapitału między krajami. Dotyczyło to zwłaszcza kapitału bezpośredniego, który jest szczególnie korzystny dla długookresowego wzrostu. Budowanie wspólnego rynku spowodowało, że Unia stała się atrakcyjniejsza na tle innych regionów świata i w związku z tym napływało więcej bezpośrednich inwestycji zagranicznych ${ }^{53}$. Dzięki postępowi integracji gospodarczej w UE, Unia jako całość stała się silniejszym partnerem gospodarczym i mogła więcej inwestować poza swoimi granicami, a także więcej inwestycji napływało do niej z tzw. krajów trzecich. Nie oznacza to, że integracja rynków finansowych w UE została zakończona. W dalszym ciągu występują pewne bariery przepływu kapitału ${ }^{54}$.

51 Co ciekawe, przed utworzeniem ERM w 1979 roku kraje członkowskie systemu miały bardziej zsynchronizowane cykle koniunkturalne ze Stanami Zjednoczonymi niż z Niemcami. Po utworzeniu ERM stały się bardziej zsynchronizowane z cyklem niemieckim (z wyjątkiem Irlandii), co może dowodzić wykształcenia się europejskiego cyklu koniunkturalnego.

52 Pierwsza z nich zliberalizowała rynek długoterminowych kredytów handlowych i emisję papierów wartościowych. Druga - ważniejsza w skutkach, gdyż realizowała pierwszy etap Unii Gospodarczej i Walutowej - wprowadzała od 1 lipca 1990 roku pełną swobodę transakcji kapitałowych (uwzględniała więc też kapitał krótkookresowy). Była to jedna z trzech swobód (kolejnymi były: swoboda osiedlania się oraz swoboda świadczenia usług - powstałe jeszcze na mocy Traktatu rzymskiego, aczkolwiek nierealizowane w praktyce), których wprowadzenie w życie było warunkiem utworzenia jednolitego rynku finansowego. Szerzej na ten temat w: E. Chrabonszczewska, L. Oręziak, Międzynarodowe rynki finansowe, Oficyna Wydawnicza SGH, Warszawa 2000, s. 48-57.

53 Towarzyszył temu proces zwiększania się wzajemnych inwestycji zagranicznych wewnątrz UE: udział wewnątrzunijnych bezpośrednich inwestycji zagranicznych w ogóle bezpośrednich inwestycji zagranicznych krajów członkowskich wzrósł z 41\% w 1984 roku do ponad 60\% w latach 1991-1993. Wpływało to korzystnie na wzrost gospodarczy krajów uczestniczących w przepływie inwestycji.

54 Wynikają one np. z prawa podatkowego, procedur ostrożnościowych w sektorze usług finansowych (np. w zakresie możliwości inwestycyjnych funduszy emerytalnych), możliwości zachowania tzw. złotej akcji przez Skarb Państwa w procesach prywatyzacji, różnych rozwiązań krajowych w zakresie opodatkowania dochodów z kapitału. Szerzej na ten temat w: E. Kawecka-Wyrzykowska, Swoboda 
Czwartym etapem integracji gospodarczej jest integracja walutowa. W początkowym, powojennym etapie integracji gospodarczej w Europie nie uwzględniano jej ${ }^{55}$ - nie znalazły się one w Traktacie rzymskim EWG. Mimo przyjęcia planu Wernera, zakładającego utworzenie w latach 1971-1980 unii ekonomicznej i walutowej, nie został on zrealizowany. Przyczynił się jednak do utworzenia Europejskiego Systemu Walutowego (ESW) poprzez utworzenie w 1972 roku tzw. węża walutowego (tj. pasma wahań walut narodowych wokół kursu centralnego o $+/-1,115 \%$ ) oraz powołanie w 1973 roku Europejskiego Funduszu Współpracy Walutowej. ESW rozpoczął działalność w 1979 roku. W jego ramach wprowadzono Europejską Jednostkę Walutową - ECU (European Currency Unit), Mechanizm Kursów Walutowych Exchange Rate Mechanizm (ERM) i mechanizm kredytowy.

Wydarzenia z początku lat 90. XX wieku, częściowo związane z recesją gospodarczą o charakterze cyklicznym, doprowadziły do załamania systemu ERM. Na skutek ataków spekulacyjnych na waluty narodowe doszło do dewaluacji (wrzesień 1992 rok) kursów brytyjskiego funta, włoskiego lira i hiszpańskiej pesety, a Włochy i Wielka Brytania wystąpiły z ERM ${ }^{56}$. W wyniku tego kryzysu Wielka Brytania do dziś pozostaje sceptyczna wobec integracji walutowej.

Traktat z Maastricht uwzględniał m.in. stworzenie Unii Gospodarczej i Walutowej (UGW) w trzech etapach: od 1 lipca 1990 roku - liberalizacja przepływów kapitałowych, co miało prowadzić do liberalizacji usług finansowych, od 1 stycznia 1994 roku - zaczęły działać instytucje UGW: Europejski Instytut Walutowy (pierwowzór Europejskiego Banku Centralnego), zaś od 1 stycznia 1999 roku - przekazywanie kompetencji krajowych banków centralnych na rzecz Europejskiego Systemu Banków Centralnych. Bardzo ważnym etapem integracji europejskich rynków finansowych było wprowadzenie nowej waluty - euro ${ }^{57}$. Pozwoliło to Unii Europejskiej, a przynajmniej części jej krajów stawić czoło procesom globalizacji i rosnącej dominacji Stanów Zjednoczonych w gospodarce światowej, mimo początkowej deprecjacji euro. Integracja ta objęła, choć w różnym stopniu, wszystkie elementy systemu

przeplywu kapitału, w: Unia Europejska, t. I, red. E. Kawecka-Wyrzykowska, E. Synowiec, Instytut Koniunktur i Cen Handlu Zagranicznego, Warszawa 2004, s. 98-100.

55 Warto odnotować głos J.M. Keynesa na rzecz stworzenia jednolitej, światowej waluty o nazwie bancor dla zapewnienia większej stabilizacji rynków finansowych po okresie Wielkiego Kryzysu i wielu kryzysów walutowych w jego trakcie, a także opinie R. Mundella (Nagroda Nobla w 1999 roku) również na rzecz jednej waluty.

56 Po dalszych napięciach na rynkach walutowych w sierpniu 1993 roku rozszerzono pasmo wahań kursów do $+/-15 \%$.

57 Nastąpiło to 1 stycznia 1999 roku w odniesieniu do operacjach bezgotówkowych, a w formie gotówkowej -1 stycznia 2002 roku. 
finansowego państw UGW, a przede wszystkim rynku pieniężnego ${ }^{58}$. W maju 1999 roku Komisja Europejska zgłosiła inicjatywy utworzenia wspólnego rynku usług finansowych w celu wsparcia wzrostu gospodarczego, co wpisywało się w realizowaną przez Unię tzw. strategię lizbońską.

Tendencje do liberalizacji rynków i pogłębiania integracji zostały zahamowane przez Parlament Europejski w 2006 roku, który przyjął tzw. dyrektywę Bolkesteina, znacznie ograniczającą - w stosunku do pierwotnej propozycji Komisji Europejskiej - swobodę wzajemnego dostępu krajów członkowskich UE do ich rynków usług. Uznał on, że tendencje do integracji i rozwoju rynków finansowych, a zwłaszcza wspólna waluta, mają jednak korzystny wpływ na wzrost gospodarczy ${ }^{59}$. Również Komisja Europejska w 2006 roku wskazywała, że należy przyspieszyć proces integracji rynków finansowych, zauważając przy tym, że dzięki temu złagodzi się wpływ wstrząsów ekonomicznych, tj. szoków zewnętrznych, ale również cyklicznych recesji na dochody i krajowe rynki kredytowe.

Przyjmuje się, że integracja rynków finansowych w UE pozwoli - poprzez ich efektywniejsze funkcjonowanie - na przyspieszenie rozwoju Unii i szybsze doganianie Stanów Zjednoczonych (co jest zgodne z celami strategii lizbońskiej). Pomoże w tym wykorzystanie efektów skali, zwiększenie dostępu - przede wszystkim dużych przedsiębiorstw - do tańszego finansowania swoich inwestycji poprzez rynki kapitałowe. Korzystać na tym będą przede wszystkim kraje, które są w strefie euro ${ }^{60}$.

Dotychczasowe doświadczenia $\mathrm{z}$ już dziesięcioletniego funkcjonowania strefy euro pokazują, że mimo początkowych obaw i silnej początkowo deprecjacji euro przynosi ona pozytywne skutki dla UE, choć o różnej sile w poszczególnych krajach. Jednym z nich jest zwiększenie odporności krajów członkowskich na zewnętrzne szoki.

58 Wspólna polityka pieniężna spowodowała w pierwszej kolejności integrację niezabezpieczonych wcześniej segmentów rynku pieniężnego, głównie rynku międzybankowego i rynku krótkookresowych instrumentów pochodnych. Następnie integracji poddały się zabezpieczone segmenty rynku pieniężnego, tj. rynek repo i rynki krótkookresowych zastawów (securities). Dzięki wprowadzeniu euro gwałtownie zaczął się rozwijać rynek obligacji, zwłaszcza w segmencie prywatnym (emisja obligacji denominowanych w euro przez prywatne przedsiębiorstwa). W strefie euro również wzrosła integracja rynków giełdowych, a także doszło do wielu fuzji o wysokiej wartości. Szerzej na ten temat w: W. Duisenberg, The role of financial markets for economic growth [przemówienie na konferencji:] „The Single Financial Market: Two Years into EMU", Oesterreichische Nationalbank, Vienna, 31.05.2001. Dokument dostępny na stronie internetowej The European Central Bank: http://www.ecb.int (4.04.2009).

59 Rezolucja Parlamentu Europejskiego w sprawie większej konsolidacji usług finansowych [2006/2081(INI)], Strasburg, 4.07.2006.

${ }^{60}$ K. Piech, op.cit., s. 28. 


\section{Wpływ integracji rynków finansowych na wzrost gospodarczy UE}

Ze względu na trudności z szacowaniem związków między rozwojem poszczególnych rynków finansowych a wzrostem gospodarczym niełatwo ocenić wpływ makroekonomiczny integracji tych rynków. Jeśli jednak integracja rynków finansowych prowadzi do ich rozwoju, a rozwój rynków finansowych powoduje wzrost gospodarczy, to również integracja rynków finansowych prowadzi do wzrostu gospodarczego. Bardzo trudno jest jednak znaleźć bardziej bezpośrednie dowody empiryczne. Niewiele jest badań z tego zakresu, a te, które są, pochodzą dopiero z ostatnich kilku lat.

Symulacje przeprowadzone dla wielu krajów przez London Economics w 2002 roku za pomocą modelu makroekonomicznego pokazały, że w wyniku integracji europejskich rynków finansowych, wpływającej m.in. na zmniejszenie kosztów finansowych, w ciągu kolejnych dziesięć lat długookresowy PKB Unii będzie wyższy o 1,1\% (o 130 mld euro w cenach z 2002 roku), aczkolwiek oddziaływanie w poszczególnych krajach będzie się różniło i zawierało w przedziale $0,3-2,0 \%$, PKB na osobę (w cenach z 2002 roku) w UE będzie wyższy o 350 euro, ogólne inwestycje biznesowe będą wyższe o prawie 6\%, a prywatna konsumpcja - o 0,8\%, ogólne zatrudnienie będzie wyższe o $0,5 \%$. Potencjalne zyski z integracji finansowej są zatem znaczne zarówno dla całej Unii, jak i poszczególnych krajów czy sektorów gospodarki, aczkolwiek nie są równo rozdystrybuowane ${ }^{61}$.

Zgodnie z wynikami badań L. Guiso i innych ${ }^{62}$ zwiększenie integracji finansowej (do takiego poziomu, jaki jest w Stanach Zjednoczonych ${ }^{63}$, lub do maksymalnego poziomu w danym kraju UE-15) zwiększy wartość dodaną całej UE-15 o 0,59-0,72\% rocznie (w zależności od przyjętego scenariusza) ${ }^{64}$, a produkcję przemysłową o 0,73 $-0,89 \%$, choć efekty wzrostowe będą się istotnie różniły między krajami i sektorami.

W pierwszym scenariuszu największy wpływ integracji rynków finansowych odnotują Belgia, Dania, Włochy (wzrost wartości dodanej o ponad 1\% rocznie), a najmniejszy - kraje najbardziej rozwinięte finansowo, tj. Holandia, Wielka Brytania

61 M. Giannetti, L. Guiso, T. Jappelli, M. Padula, M. Pagano, Financial Market Integration, Corporate Financing and Economic Growth. Final Report, „Economic Papers” Nr 179, European Commission, Directorate-General for Economic and Financial Affairs, Brussels 2002, s. 43.

62 L. Guiso, T. Jappelli, M. Padula, M. Pagano, op.cit., s. 3.

63 Przyjmuje się, że USA mogą być wzorem dla Europy ze względu na to, że mają najbardziej rozwinięte rynki finansowe. Szerzej na ten temat w: R.G. Rajan, L. Zingales, Financial Dependence and Growth, „American Economic Review” Vol. 88, Nr 3, 1998, s. 559-586.

64 Wcześniejsze badania (Giannetti i inni 2002) pokazywały wpływ na wartość dodaną rzędu $0,75-0,94 \%$. 
i Szwecja (poniżej 0,5\% rocznie). W drugim scenariuszu największy wpływ odnotują Niemcy (wzrost wartości dodanej o ponad $0,8 \%$ rocznie), a najmniejszy - Wielka Brytania (poniżej $0,2 \%$ rocznie). Warto zauważyć, że odpowiada to wzorom rozwoju rynków finansowych - Wielka Brytania jest ewidentnym przykładem kraju o bardzo rozwiniętym rynku papierów wartościowych (wysoka kapitalizacja giełdy), a Niemcy są wzorcem rozwoju systemu bankowego ${ }^{65}$.

Kraje o względnie słabych strukturach finansowych, np. Belgia, Dania, Niemcy, Włochy, będą bardziej korzystały na integracji rynków finansowych niż kraje o względnie wysokim poziomie rozwoju finansowego, np. Wielka Brytania, Szwecja, Holandia, które niewiele zyskają. Wyniki te w dużej mierze zostały potwierdzone $e^{66}$ już nie na poziomie przemysłów (jak to było wyżej), ale na podstawie dużej próby firm z 26 krajów. Rozwój finansowy ma większy wpływ na małe i średnie firmy ${ }^{67}$ niż na duże, gdyż te na ogół mają większe możliwości korzystania z międzynarodowych rynków finansowych. Wpływ integracji finansowej na rozwój przedsiębiorstw będzie zatem większy w krajach, w których jest więcej małych i średnich przedsiębiorstw, tj. w Austrii, Belgii, Grecji, Włoszech, Hiszpanii i Szwecji. Ciekawe może być sprawdzenie, jak integracja rynków finansowych wpłynęłaby na sytuację nowych członków UE, w tym Polski. L. Guiso i inni oszacowali, że spośród sześciu analizowanych krajów największy wpływ na wzrost sprzedaży w sektorze wytwórczym będzie na Litwie i w Polsce, a najmniejszy - w Czechach ${ }^{68}$.

Innym interesującym zjawiskiem jest oddziaływanie integracji na konwergencję. Według A.P. Thirlwalla nie ma dowodów na konwergencję stóp bezrobocia w Europie (na poziomie regionów) oraz dochodu na osobę od lat 80 . ze względu na zmniejszenie barier handlu i przepływu czynników produkcji (we wcześniejszych okresach były one widoczne) ${ }^{69}$. Pozytywne oddziaływanie procesów integracji może być zatem bardzo odległe w czasie. Głównym czynnikiem różnicującym regiony są różne nakłady na działalność badawczo-rozwojową.

\footnotetext{
65 Dlatego oba te systemy określa się jako anglosaski i kontynentalny (czy niemiecki).

66 L. Guiso, T. Jappelli, M. Padula, M. Pagano, op.cit., s. 3.

${ }^{67}$ Zdefiniowane jako zatrudniające mniej niż 200 osób.

${ }^{68}$ L. Guiso, T. Jappelli, M. Padula, M. Pagano, op.cit., s. 3.

69 A.P. Thirlwall, Growth and Development. With Special Reference to Developing Economies, $8^{\text {th }}$ ed., Palgrave-Macmillan, Basingstoke-New York 2006, s. 240-241.
} 


\section{Korzyści i zagrożenia płynące z integracji}

Integracja rynków finansowych niesie zarówno korzyści, jak i zagrożenia. Korzyści należy upatrywać w możliwości zdynamizowania wzrostu PKB, zagrożenia zaś $\mathrm{w}$ istnieniu coraz silniejszych powiązań pomiędzy rynkami poszczególnych krajów i działającymi na nich pośrednikami finansowymi.

Według szacunków Komisji Europejskiej ${ }^{70}$ powstanie jednolitego rynku usług finansowych może zwiększyć wzrost gospodarczy o blisko 1,1\%, a zatrudnienie o blisko $0,5 \%$. Integracja detalicznego rynku usług finansowych mogłaby z kolei przyczynić się do osiągnięcia korzyści w wysokości około 0,7\% unijnego PKB ze względu na spadek stóp procentowych. Ponadto integracja rynków finansowych powinna przyczynić się do obniżenia kosztów transakcyjnych zarówno na rynku akcji, jak i obligacji, co może mieć długoterminowy korzystny wpływ na poziom PKB. Stwierdzono także, że koszty transakcyjne związane z przeprowadzaniem rozliczeń są jednym $\mathrm{z}$ istotnych czynników utrudniających integrację rynków finansowych, a zatem ich ograniczenie powinno pozytywnie wpłynąć na procesy integracji.

Inne badania wykazały, że osiągnięcie w UE poziomu rozwoju finansowego zbliżonego do istniejącego w Stanach Zjednoczonych oznaczałoby wzrost w sektorze wytwórczym od $0,6 \%$ do $0,7 \%$ w skali roku w zależności od scenariusza ${ }^{71}$. Łatwiejszy dostęp do finansowania powinien przyczynić się do pobudzenia inwestycji i tym samym rozwoju gospodarczego.

Biorąc pod uwagę wcześniej opisane działania związane z integracją transgraniczną, można stwierdzić, że nie ma barier wejścia na rynek lokalny przez banki zagraniczne. Dla rozwoju gospodarczego ważne jest to, aby banki, które wchodzą na rynek lokalny, lepiej oceniały ryzyko niż banki na nim działające. Może się to przyczynić do ogólnej poprawy oceny ryzyka kredytowego, a tym samym - docelowo do obniżenia ceny kredytu ${ }^{72}$. Podobne wnioski można sformułować w odniesieniu do działalności innej niż kredytowa - możliwości swobodnego wejścia banków na rynek przyczyniają się do wzrostu konkurencji, a tym samym powinny mieć pozytywny wpływ zarówno na jakość świadczonych usług, jak i ich ceny.

70 C. Stirbu, op.cit., s. 17 oraz Commission of the European Communities, Tracking EU financial integration, „Commission Staff Working Paper” Nr SEC(2003)628, Commission of the European Communities, Brussels 2003, s. 11-16.

71 L. Guiso, T. Jappelli, M. Padula, M. Pagano, op.cit., s. 3-4.

72 L. Kaas, Financial market integration and loan competition. When is entry deregulation socially beneficial?, ,Working Paper Series” Nr 403/2004, European Central Bank, Frankfurt 2004, s. 19-21. Dokument dostępny na stronie internetowej The European Central Bank: http://www.ecb.int (5.04.2009). 
Integracja rynków finansowych ma także swoje ciemne strony, które podczas obecnego kryzysu ujawniły się na rynku amerykańskim, ale też na rynku europejskim. Mogą one stanowić istotne zagrożenie dla gospodarki unijnej. Szczególnie ważnym problemem jest efekt zarażania (contagion effect). Efekt zarażania można rozpatrywać w kontekście dwóch typów szoków: makro i mikro ${ }^{73}$. Szoki makro mogą wynikać z załamania koniunktury gospodarczej lub innych czynników, jak: stopy procentowe, kursy walutowe czy załamanie na rynku akcji. Szoki mikro zaś mogą przenosić się dwoma kanałami: poprzez kanał informacyjny bądź poprzez wzajemne ekspozycje na rynku międzybankowym lub w systemie płatniczym, które mogą wywołać tzw. efekt domina. Dla nowych krajów unijnych (EU-10+2) ważny jest także kanał wzajemnych powiązań kapitałowych w relacjach spółka matka i spółka córka.

Rynek międzybankowy operacji w euro jest rynkiem zintegrowanym, a więc przenoszenie się efektu zarażania byłoby na nim dosyć łatwe. Upadłość jednego $\mathrm{z}$ istotnych graczy na tym rynku mogłaby wywołać problemy w innych bankach, które pożyczyły mu środki. Kłopoty tych banków mogłyby z kolei przenieść się na kolejne itd. Istotne jest to, że do tej pory jeszcze nie wypracowano na szczeblu UE mechanizmów podziału kosztów kryzysu finansowego, którego wystąpienie - jak pokazują doświadczenia różnych krajów - często wymagało ponoszenia dosyć wysokich, w relacji do PKB, kosztów restrukturyzacji ${ }^{74}$. Główny nacisk przy zarządzaniu kryzysowym położono na dobrowolną współpracę i wymianę informacji pomiędzy różnymi instytucjami (organy nadzoru, banki centralne i ministerstwa finansów krajów UE) na szczeblu UE, na szczeblu regionalnym (np. kraje skandynawskie), jak i porozumienia dwustronne. Podkreślono także, że odpowiedzialność finansową ponoszą przede wszystkim właściciele ${ }^{75}$.

Za pocieszające należy uznać to, że banki pożyczając sobie środki na rynku międzybankowym, oceniają swoją kondycję, a więc kłopoty finansowe danego banku powinny zostać spostrzeżone w odpowiednim czasie i banki z nim współpracujące na rynku międzybankowym powinny odpowiednio zareagować, nie pożyczając mu środków.

73 M. Schüler, The threat of systemic risk in banking - evidence for Europe, „Discussion Paper” Nr 02-21, Centre for European Economic Research (ZEW), Mannheim 2002, s. 4.

${ }_{74}$ M. Iwanicz-Drozdowska, Kryzysy bankowe w Europie. Kraje uprzemysłowione, w: Kryzysy bankowe. Przyczyny i rozwiązania, red. M. Iwanicz-Drozdowska, Polskie Wydawnictwo Ekonomiczne, Warszawa 2002, s. 61-111.

75 L. Papademos, ECB Financial Stability Review December 2006 [materiały konferencyjne], European Central Bank, Frankfurt am Main, 11.12.2006, s. 9-10. Dokument dostępny na stronie internetowej The Bank for International Settlements: http://www.bis.org (6.04.2009). 
Jak wskazują badania ${ }^{76}$, zwłaszcza duże banki są wrażliwe na zmiany zachodzące na rynku unijnym. Były one przyczyną $80 \%$ zmian wariancji ryzyka podejmowanego przez banki, a więc powinny być szczególnie monitorowane. Należy także pamiętać o istnieniu - silnie krytykowanej w Stanach Zjednoczonych - doktryny „zbyt duży, żeby upaść” (too big to fail) i jej odmiany „zbyt ważny, żeby upaść” (too important to fail). Zgodnie z tymi doktrynami duży, ważny bank nie jest pozostawiany samemu sobie w przypadku kłopotów, lecz podejmowane są działania mające na celu jego uratowanie, a przede wszystkim uratowanie oszczędności ludności. System gwarantowania depozytów w żadnym kraju nie byłby w stanie przetrzymać upadłości największego banku7 .

Efekt zarażania może wystąpić także w ujęciu międzysektorowym. Polegałoby to na przenoszeniu się niekorzystnych zjawisk z podmiotu działającego w danej grupie kapitałowej na inny podmiot będący w tej samej grupie. Zarażanie może mieć charakter faktyczny - rzeczywiste pogorszenie kondycji, bądź psychologiczny - reakcja klientów kojarzących logo grupy.

W przypadku krajów „nowej” Unii możliwa jest jeszcze inna przyczyna efektu zarażania, a mianowicie zarażenie spółki córki przez spółkę matkę, co jest szczególnie ważne ze względu na strukturę własności pośredników finansowych, gdzie przeważa kapitał zagraniczny. Spółka matka, która przeżywa kłopoty finansowe, mogłaby przetransferować straty do spółki córki, doprowadzając ją w skrajnym przypadku do upadłości. Ucierpiałaby na tym wprawdzie reputacja spółki matki, ale ratowanie własnej kondycji w kraju pochodzenia mogłoby być priorytetem ${ }^{78}$.

\section{Podsumowanie}

Zaprezentowane rozważania pokazują, że zjawisko integracji rynków finansowych jest złożone. Obejmuje ono liberalizację rynków, pogłębianie się integracji, również w kierunku obejmującym rynki kapitałowe, by ewentualnie doprowadzić do przyjęcia wspólnej waluty. Jak pokazano, liberalizacja rynków finansowych jest korzystna dla świata jako całości, a także na ogół jest korzystna dla poszczególnych krajów. Zwiększa dostęp do kapitału, którego często brakuje w krajach o słabiej

76 A. Brasili, G. Vulpes, Banking integration and co-movements in EU banks' fragility, Bank of Spain, Madrid 2006, s. 16. Dokument dostępny na stronie internetowej The Munich Personal RePEc Archive: http://mpra.ub.uni-muenchen.de (6.04.2009).

77 M. Iwanicz-Drozdowska, Integracja rynków..., op.cit., s. 17.

78 Ibidem. 
rozwiniętym systemie finansowym, poprawia alokację kapitału, zwiększa efektywność funkcjonowania gospodarki.

Liberalizacja krajowego rynku finansowego i otwarcie go na wpływy zewnętrzne powodują jednak wzrost wpływu koniunktury zagranicznej na gospodarkę kraju ${ }^{79}$. Z jednej strony może to mobilizować rządy do poprawy jakości prowadzonej polityki gospodarczej. $Z$ drugiej jednak strony, jeśli rządy nie mogą poradzić sobie z problemami gospodarczymi lub nie przewidzą na czas zagrożeń (i nie przeciwdziałają im, np. nie stworzą odpowiednich instytucji), może wystąpić kryzys finansowy. Rynki finansowe to przy tym nie tylko kapitał spekulacyjny (często obwiniany za kryzysy), ale również inwestycje bezpośrednie, które nierzadko istotnie, bardzo pozytywnie przyczyniają się do wzrostu zatrudnienia, rozwoju technologicznego czy w ogóle do rozwoju gospodarczego. Również integracja walutowa - jeśli jest odpowiednio przygotowana - przynosi znaczne korzyści ekonomiczne.

Integracja rynków finansowych to jednocześnie możliwość osiągnięcia znacznych zysków i - w przypadku niedostosowania instytucjonalnego - ryzyko kryzysów finansowych (i recesji gospodarczych). Biorąc jednak pod uwagę to, że po każdym kryzysie przychodzi kiedyś okres rozwoju, a także to, że fazy pomyślnej koniunktury są dłuższe niż okresy recesji, w sumie daje to na ogół bardzo pozytywny rezultat.

Procesy międzynarodowej integracji finansowej mają korzystny wpływ na wzrost gospodarczy na jego różnych płaszczyznach: kraju, regionów, przemysłów i firm. Są one tym większe, im głębsza jest integracja. $Z$ tego względu powinny być kontynuowane dążenia do pełniejszej integracji - zarówno międzynarodowej, regionalnych ugrupowań integracyjnych, jak i pojedynczych krajów. Korzyści z integracji rynków finansowych nie wynikają tylko $z$ koncepcji teoretycznych, ale znajdują potwierdzenie w wynikach (nielicznych jeszcze) badań empirycznych. Pokazują one, że dzięki integracji finansowej wzrost gospodarczy krajów integrujących się może być znacznie wyższy - nawet o $2 \%$ rocznie w długim okresie. Co ciekawe, największe korzyści z integracji osiągają kraje o słabiej rozwiniętych systemach finansowych.

W celu przyspieszenia wzrostu gospodarczego niezbędne było i jest wspomaganie integracji rynków finansowych na szczeblu UE. Z jednej strony procesy te mogą ułatwić przedsiębiorstwom dostęp do kapitału i obniżyć poziom cen usług finansowych. $\mathrm{Z}$ drugiej strony trzeba jednak mieć na względzie niekorzystne zjawiska, które mogą wynikać z integracji. Dalszą integrację rynków finansowych w UE należy uznać za konieczność, choć proces ten wymaga szczególnej uwagi ze strony krajów niżej rozwiniętych, gdzie dominuje kapitał zagraniczny. Wśród nowych krajów członkowskich

$79 \mathrm{~W}$ tym opinii inwestorów zagranicznych (także korporacji transnarodowych) na temat perspektyw rozwoju kraju docelowego inwestycji. 
UE jedne z największych korzyści z integracji może odnotować Polska. Należy też pamiętać, że integrację rynków finansowych wspomaga przyjęcie wspólnej waluty, co jest jednym $z$ wielu argumentów na rzecz wejścia naszego kraju do strefy euro.

\section{Financial market integration in the European Union}

The integration of financial markets is one of the stages of economic integration. The trends for the integration of financial markets is observed both on a global scale, as well as its various regions. The integration of financial markets may occur as a result of actions by the authorities, but also by the international free market processes - globalization.

Speaking about the integration of EU financial markets, we mean creating opportunities for free movement of capital and financial services in the EU and the single currency. As a result of increase in the financial integration process in Europe the value of the flow of capital between countries has significantly increased. With the progress of economic integration in the $\mathrm{EU}$, the $\mathrm{EU}$ as a whole has become a stronger business partner and was able to invest more beyond its borders, as well as more investments flowed from the third countries.

The integration of financial markets through greater development of the financial markets is leading to faster economic growth. It can bring many benefits, but also risks. Benefits should be seen in the possibility to boost the GDP growth, the risks in the existence of increasingly stronger links between national markets and intermediaries acting on that markets. A particularly important issue is the contagion effect. Additionally, in case of institutional mismatches on the side of economic policy, financial integration can also have negative effects on the economy, such as greater probability of financial crisis and economic recession, because the price for increased integration of financial markets is an increase in the risk of financial crises. Economic growth stimulated by the development of financial markets should be accompanied by proper regulation of markets to prevent future crisis. However, it must be also remembered that the growth of the institutions may limit the development of markets. 


\section{L'intégration des marchés financiers au sein de l'Union européenne}

L'intégration des marchés financiers est l'une des étapes de l'intégration économique. Cette tendance est observée à la fois à léchelle mondiale, ainsi que dans différentes régions. L’intégration des marchés financiers peut se produire à la suite des mesures prises par les autorités, mais aussi par les processus internationaux de libre marché dans le cadre de la mondialisation. L'intégration des marchés financiers européens est liée à la possibilité de la libre circulation des capitaux et de la libre prestation des services financiers dans l'UE ainsi quà l'introduction de la monnaie unique. En raison du développement de cette intégration en Europe la valeur des flux de capitaux entre les pays a considérablement augmenté. Grâce au progrès de l'intégration économique dans l'UE, cette organisation dans son ensemble est devenue un partenaire plus fort en matière déconomie - elle a pu investir plus à létranger. En outre, le flux croissant d'investissements en provenance des pays tiers a été noté. L'intégration des marchés financiers à travers un plus grand développement de ces marchés conduit à une croissance économique plus rapide. Ce processus peut apporter de nombreux avantages, mais aussi certains risques. Les avantages résultent de la possibilité de dynamiser la croissance du PIB, pendant que les risques sont liés aux relations de plus en plus étroites entre les marchés nationaux et les intermédiaires financiers qui opèrent sur eux. Un problème particulièrement important est l' »effet de contagion«. En outre, dans le cas d'inadéquations institutionnelles en matière de politique économique, l'intégration financière peut avoir également des effets négatifs sur l'économie. La crise financière et la récession économique peuvent se produire - une intégration accrue des marchés financiers entraîne un risque accru de crises financières. Parallèlement à la croissance économique, qui résulte de l'évolution des marchés financiers, il est important d'assurer une bonne régulation des marchés afin de prévenir une crise. Cependant, il faut garder à l'esprit que l'expansion des institutions peut limiter le développement des marchés 